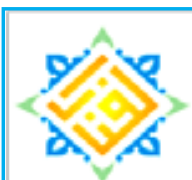

AL-FANAR

Jurnal Ilmu Al-Quran dan Tafsir
Volume 4, Nomor 2, 2021, hlm. 113-134

P-ISSN: 2622-2280 | E-ISSN: 2622-4658

https://ejurnal.iiq.ac.id/index.php/alfanar

\title{
Ekologi dan Kerusakan Lingkungan dalam Persepektif Al-Qur'an
}

\section{Sholehuddin}

Sekolah Tinggi Ilmu Shuffah Al-Qur'an Abdullah bin Mas'ud (SQABM) Lampung soleh.addin@gmail.com

DOI: $10.33511 /$ alfanar.v4n2.113-134

Submitted: 2021-06-21, Revised: 2021-07-09, Accepted: 2021-08-15

\begin{abstract}
Ecosystem is an overall unified arrangement of elements of the environment that influence each other in creating balance, order and sustainability. The discourse on environmental conservation has become an actual issue in the midst of the threat of a global crisis as a consequence of disasters, climate change, global warming, erratic seasonal changes, decreased quality of life and the threat of destruction of the earth. This condition triggers the anxiety and worry of mankind about the extinction of the earth. This study will answer how the Koran talks about the environment and its impact on human life. The design of this research is a qualitative type of literature. The data collection technique is the documentation of collecting environmental damage verses. The analysis uses a comparative interpretive, namely examining verses on environmental damage, comparing them, then concluding them through inductive thinking. The results of the study prove that environmental damage is caused by polytheists, hypocrites, greedy and selfish people. Solutions for strengthening monotheism, awareness of environmental law, and moral natural resource management.
\end{abstract}

Keywords: Ecology, Damage, Environment, Al-Qur'an

\section{Abstrak}

Ekosistem adalah tatanan kesatuan menyeluruh antar unsur lingkungan hidup yang saling memengaruhi dalam menciptakan keseimbangan, keteraturan dan kelestarian. Diskursus konservasi lingkungan hidup menjadi isu aktual di tengah ancaman krisis global sebagai konsekuensi terjadinya bencana, perubahan iklim, pemanasan global, perubahan musim tak menentu, penurunan kualitas hidup dan ancaman kehancuran bumi. Kondisi ini menejadi pemicu kegelisahan dan khawatir umat manusia akan terjadinya kepunahan bumi. Penelitian ini akan menjawab bagaimana Al-Qur'an berbicacara tentang lingkungan hidup dan dampaknya bagi kehidupan umat manusia. Desain penelitian ini adalah kualitatif jenis kepustakaan. Teknik pengumpulan data adalah dokumentasi mengumpulkan ayat-ayat kerusakan lingkungan. Analisis menggunakan interpretatif komparatif, yaitu menelaah ayat-ayat kerusakan lingkungan hidup, membanding-bandingkan, kemudian menyimpulkannya melalui cara berpikir induktif. Hasil penelitian membuktikan kerusakan lingkungan terjadi akibat manusia musyrik, munafik, serakah dan egois. Solusi penguatan tauhid, penyadaran hukum lingkungan hidup, dan pengelolaan sumber daya alam berakhlak.

Kata Kunci: Ekologi, Kerusakan, Lingkungan, Al-Qur'an 


\section{PENDAHULUAN}

Manusia merupakan bagian dari alam yang paling berhak menjaga keseimbangan ekosistem untuk kelangsungan hidupnya. Selama ini, ada di antara mereka yang beranggapan bukan bagian dari alam sehingga dengan bebas memanfaatkan segala sesuatu yang ada di alam, tanpa memperhatikan pelestarian (konservasi) dan keberlangsungannya. Padahal lingkungan alam, itu mempengaruhi hidup manusia dan sebaliknya manusia hidup dipengaruhi oleh lingkungan. Manusia berada dalam lingkungan yang tidak dapat terpisahkan dari pada alam sekitar. Dengan begitu, lingkungan menjadi bagian penting bagi makhluk hidup, khususnya manusia. Satu hal yang patut diketahui bahwa salah satu sumber daya alam bagi seluruh makhluk hidup yang merupakan bagian dari kerangka besar sistem ekosistem adalah ekologi yang terbentuk dari hubungan timbal balik antar makhluk hidup dengan lingkungannya. Ekologi menjadi parthner sejati bagi manusia dalam menciptakan iklim yang kondusif, ramah, teratur dan berkelanjutan.

Adanya faktor perkembangan ilmu pengetahuan dan teknologi serta tumbuhnya industri yang begitu pesat pada saat ini telah memberikan pengaruh tersendiri pada berbagai aspek, baik yang berdampak positif terhadap ekologi maupun negatif. Dampak negatif berupa kerusakan lingkungan yang dipicu oleh dua faktor, yaitu: faktor alami dan faktor aktivitas manusia. Faktor alami berupa bencana alam dan cuaca yang tidak menentu sebagai konsekuensi faktor usia bumi (alam) yang sudah mencapai ribuan miliar tahun, yang tentunya secara alami akan mengalami penuaan dan pelemahan daya tahan struktur bumi. Termasuk kategori bencana alam adalah banjir, tanah longsor, tsunami, gunung meletus, ataupun gempa bumi. Pengaruhnya, selain berbahaya bagi keselamatan manusia dan makhluk hidup lain, juga dapat mengakibatkan rusaknya lingkungan. Faktor kerusakan lingkungan akibat aktivitas manusia, ini tentu lebih tragis lagi bahayanya karena tindakan manusia mengeksploitasi sumber daya alam secara besar-besaran, bersifat sistemik, terstruktur, masif, tidak ramah lingkungan, tanpa mempertimbangkan efek buruk ekosistem dan struktur tanah jangka panjang seperti tindakan penggundulan hutan, alih fungsi lahan secara liar, pencemaran udara, air, dan tanah tanpa terasa menjadi pemicu inti proses percepatan bumi menemui kehancuran dan kepunahannya. Penelitian ini akan menjawab bagaimana Al-Qur'an berbicara tentang lingkungan hidup dan dampaknya bagi kehidupan umat manusia.

Paradigma penelitian ini adalah penelitian kualitatif dengan jenis penelitian kepustakaan, karena semua data diambil dari sumber utama yakni ayat-ayat Al-Qur'an yang membahas tentang lingkungan hidup. Teknik pengumpulan data menggunakan dokumentasi dengan urutan kerja mengumpulkan ayat-ayat yang di dalamnya terdapat arti kerusakan lingkungan. Langkah berikutnya memahami kata kunci merujuk pada kitab-kitab tafsir, terutama kitab tafsir Ibnu Katsir, al-Maraghi dan al-Misbah. Analisis data menggunakan interpretatif komparatif, yakni melakukan penafsiran terhadap ayat-ayat tentang lingkungan hidup berdasarkan kitab tafsir tersebut, kemudian membandingkannya. Langkah terakhir mengambil kesimpulan dengan pola berpikir induktif. Hasil penelitian membuktikan kerusakan lingkungan terjadi akibat manusia musyrik, munafik, serakah dan egois. Solusi penguatan tauhid, penyadaran hukum lingkungan hidup, dan pengelolaan sumber daya alam berakhlak. 


\section{KONSEP EKOLOGI DAN LINGKUNGAN ALAM}

Ekologi termasuk dalam cabang ilmu Biologi yang mempelajari cara-cara berhubungan antar organisme di dalam lingkungan sekitarnya ${ }^{1}$ dan telah berkembang sesuai perjalanan sejarah manusia hidup dan berkembang biak. Seorang peneliti berkebangsaan Jerman, Ernst Haeckel namanya menjelaskan bahwa ekologi merupakan sebuah disiplin ilmu pengetahuan yang bersifat komprehensif berhubungan dengan proses organisme terhadap lingkungan. Para biologiwan yang terkenal di abad ke-18 dan ke-19 sebenarnya telah banyak bermunculan yang telah memberikan sumbangsih pikiran dalam bidang ini, sekalipun pada saat itu belum menggunakan kata "ekologi". Misalnya, Antony Van Leeuwenhoek yang lebih dikenal sebagai pelopor ahli mikroskop pada tahun 1700 -an, memprakarsai pula pengkajian rantai makanan dan pengaturan populasi. Tulisan serupa yang ditulis botaniwan asal Inggris bernama Richard Bradley, juga menyatakan bahwasaanya ia sangat memahami betul hal produktivitas biologis. Dengan demikian, ketiga bidang yang dikemukakan tersebut dianggap sangat penting dalam proses ekologi mutakhir. ${ }^{2}$ Juga, ekologi dikenal sebagai ilmu tentang hubungan timbal balik antar mahluk hidup dengan sesamanya dan dengan benda-benda tidak hidup di sekitarnya, sebagaimana dijelasakan Utomo bahwa makhluk hidup dalam kasus pertanian adalah tumbuh-tumbuhan, sedangkan lingkungannya dapat berupa udara, tanah, air, unsure-unsur hara, dan lain-lain. Kini, istilah ekologi lebih dipahami sebagai sebuah ilmu yang mempelajari fungsi-fungsi dan struktur dari pada alam. Bahkan ekologi dikenal sebagai ilmu yang mempelajari rumah tangga makhluk hidup, merupakan disiplin cabang ilmu dari biologi yang menjadi mata rantai fisik dan proses biologi serta bentuk-bentuk yang menjembatani antara ilmu alam dan ilmu sosial. ${ }^{3}$

Substansi ekologi merupakan cabang dari disiplin ilmu biologi (ilmu hayat), yang terbagai pada dua varian berdasarkan pembagian lapisan vertikal dan taksonomi (keratan). Contoh lapisan yang tergolong vertikal, antara lain: fisiologi (ilmu tentang faal makhluk hidup), genetika (ilmu tentang sifat keturunan), morfologi (ilmu tentang bentuk luar tubuh), ekologi (ilmu tentang rumah makhluk hidup), histologi (ilmu tentang jaringan mikroskopis), anatomi (ilmu tentang bagian dalam tubuh), embriologi (ilmu tentang perkembangan embrio), evolusi (ilmu tentang perkembangan dan pertubungan makhluk hidup), teratologi (ilmu tentang praduga bayi cacat dalam kandungan), organologi (ilmu tentang organ), ontogeni (ilmu tentang perkembangan makhluk hidup dari sejak embrio hingga dewasa), dan lain sebagainya. Sedangkan, contoh berdasarkan lapisan taksonomi adalah sebagai berikut: mikologi (ilmu tentang jamur), mikrobiologi (ilmu tentang jasad renik), entomologi (ilmu tentang serangga), ornitologi (ilmu tentang burung), botani (ilmu tentang tumbuhan), zoologi (ilmu tentang binatang), virologi

\footnotetext{
${ }^{1}$ Vanya Karunia Mulia Putri, Ekologi: Definisi, Ruang Lingkup, Asas dan Manfaatnya, https:// www.kompas.com/skola/read/2021/04/16/163119269/ekologi-definisi-ruang-lingkup-asas-danmanfaatnya?page $=$ all

${ }^{2}$ R. \& Wahyuni K.D. Ekologi dan Lingkungan Hidup, (Gorontalo: UNG Press, 2009) dan Amelia Indah Sari, Hubungan Ekologi Dengan Pelestarian Lingkungan dalam https://www. researchgate.net/ publication/ 342183770_Hubungan_Ekologi_Dengan_Pelestarian_Lingkungan/ link/ 5ee7da6d299bf1 faac56aaf4/download

${ }^{3}$ Utomo, S.W. dkk., Pengertian, ruang Lingkup Ekologi dan Ekosistem, http//repository.ut.ac. id/ 4305/1/BIOL4215-M1.pdf, diakses mei 2021
} 
(ilmu tentang virus), bakteriologi (ilmu tentang bakteri), dan lain sebagainya ${ }^{4}$ yang dalam klasifikasi, unsur-unsur, peran dan fungsinya dapat dilihat pada uraian ruang lingkup ekologi berikut.

\section{Ruang Lingkup Ekologi}

Ruang lingkup ekologi sangat luas yang sebelumnya hanya mempelajari tentang makhluk hidup yang memiliki tingkat organisasi paling sederhana (rendah) sampai ke level organisasi paling kompleks (tinggi). Hal ini dapat dibaca pada spektrum biologi sebagai berikut: Pertama, Molekul merupakan sekumpulan unsur-unsur yang membentuk suatu senyawa kimia. Molekul akan menyusun organ-organ sel, seperti: membran sel plasma yang tersusun dari molekul-molekul protein. Kedua, Organisme berhubungan dengan jasad hidup merupakan kumpulan sistem organ yang membentuk individu. Ketiga, Populasi yaitu kelompok makhluk hidup satu spesies yang hidup pada suatu habitat yang sama. Habitat merupakan tempat menetap suatu makhluk hidup yang dalam perkembangbiakannya terjadi interaksi antar spesies, seperti: asimilasi, perkawinan, dan perlindungan satu sama lain. Keempat, Komunitas adalah keragaman spesies merupakan variasi berbagai jenis organisme yang membentuk komunitas atau perkumpulan populasi berbagai jenis makhluk hidup yang saling berinteraksi dan menempati lingkungan yang sama ${ }^{5}$.

Pada hakikatnya konsep ekologi sendiri merupakan bentuk keterkaitan dan ketergantungan antara seluruh komponen ekosistem yang harus dipertahankan dalam kondisi stabil dan seimbang (homeostatis) yang cenderung untuk menahan adanya perubahan dan selalu berada dalam posisi moderasi. Adanya sistem ekosistem makhluk hidup, maka ekologi dianggap mampu memelihara dan mengatur diri sendiri seperti dalam hal komponen penyusunnya yaitu organisme dan populasi, sehingga ekosistem dapat dianggap suatu kibernetika (struktur sistem regulasi) di alam. ${ }^{6}$ Menurut epistemologi ekologi tumbuhan, terdapat dua model teori yang dapat dipelajari, yaitu teori autekologi dan teori sinekologi. Autekologi (ekologi spesies) adalah kajian tentang sejarah hidup suatu spesies tumbuhan, perilaku, dan adaptasinya terhadap lingkungan; sedangkan sinekologi (ekologi komunitas) adalah kajian tentang kelompok organisme tumbuhan yang tergabung dalam satu kesatuan dan saling berinteraksi dalam daerah tertentu. ${ }^{7}$ Sementara ekologi menurut habitatnya diklasifikasikan pada beberapa kelompok, yaitu: ekologi bahari atau kelautan, salah satu contohnya adalah ekologi laut tropis. Ekologi estuaria, yang merupakan bagian dari lingkungan perairan yang menjadi daerah percampuran antara air laut dan air tawar yang berasal dari sungai, sumber air tawar lainnya, seperti: saluran air dan genangan air tawar. Guna pelestarian sistem lingkungan hidup ini, perlu kiranya kajian dan analisa mendalam terahadap

\footnotetext{
${ }^{4}$ Safitri, D. Ekoturisme Dalam Ekologi Sosial, (Tangerang: Pustaka Mandiri, 2019)

${ }_{5}^{5}$ Amelia Indah Sari, Hubungan Ekologi Dengan Pelestarian Lingkungan dalam https://www. researchgate.net/publication/342183770_Hubungan_Ekologi_Dengan_Pelestarian_Lingkungan/ link/5ee7da6d299bf1 faac56aaf4/download

${ }^{6}$ Darwis, H \& Mas'ud, H. (2017). Kesehatan Masyarakat dalam Perspektif Sosioantropologi. Makassar: SAH MEDIA dalam https:// www. researchgate.net/ publication/ 342183770_Hubungan_ Ekologi_Dengan_Pelestarian_Lingkungan/link/5ee7da6d299bf1 faac56aaf4/download

7 Jayadi, E.M. (2015). Ekologi Tumbuhan. Mataram: Institut Agama Islam Negeri (IAIN) Mataram
}

116 | Al-Fanar: Jurnal Ilmu Al-Qur'an dan Tafsir 
hubungan dan manfaat ekologi lingkungan hidup dengan makhluk-makhluk Allah di bumi, khususnya manusia yang agar terwuju kebersamaan yang stabil, serasi dan berkesinambungan.

\section{Ekologi Lingkungan Hidup}

Lingkungan hidup, yang sering dihubungkan dengan manusia dan atau makhluk Allah lainnya sebenarnya berakar dari penerapan makna ekologi. Lingkungan merupakan sebuah kajian terhadap perilaku dan sikap manusia tentang tanggung jawab dan kewajibannya dalam mengelola alam sebagai tepat hidup makhluk, termasuk manusia. Menurut UU Nomor 23 Tahun 1997, lingkungan hidup adalah sistem kehidupan yang merupakan kesatuan ruang dengan segenap benda, keadaan, daya dan makhluk hidup termasuk manusia dengan perilakunya yang mempengaruhi keberlangsungan tata cara kehidupan dan bentuk kesejahteraan manusia serta makhluk-makhluk hidup lainnya. Secara detail Armour dalam Soerjani menjelaskan bahwa lingkungan adalah jumlah semua benda dan kondisi yang ada dalam ruang yang ditempati manusia yang mempengaruhi kehidupannya sebagai sebuah sistem kompleks yang terdapat di luar seseorang yang dapat menentukan perkembangan dan pertumbuhan organisme. Dalam kacamata environmental science ${ }^{8}$ (paradigma ilmu lingkungan) berpandangan bahwa lingkungan adalah metode ilmiah untuk menghadapi kehidupan manusia yang kompleks di bawah tatanan kehidupan alam semesta, sehingga hal itu merupakan kombinasi hukum manusia dan hukum alam berdasarkan teori, perangkat dan aplikasinya yang mengacu pada komponen nilai kemanusiaan yang dilakukan melalui keterampilan profesional dan sistematika ilmiah. Atas dasar pengertian ini, ilmu lingkungan merupakan ilmu pengetahuan murni yang monolitik yang dapat digunakan untuk mengkaji dan memahami fenomena alam yang dapat diketahui melalui penelaahan dan penelitian seksama tentang kerusakan lingkungan hidup dan berbagai variannya dalam sebuah realita.

\section{FENOMENA KERUSAKAN LINGKUNGAN HIDUP}

Lingkungan hidup adalah sebuah medan yang telah Allah Ta'ala ciptakan sebagai tempat manusia hidup, untuk dikaji dan dipahami secara komprehensif sebagai sebuah kesatuan ruang dengan semua benda, daya, keadaan, dan makhluk hidup, termasuk manusia dan perilakunya, yang mempengaruhi alam itu sendiri, kelangsungan perikehidupan, dan kesejahteraan manusia serta makhluk hidup lain. ${ }^{9}$ Ruang merupakan berbagai komponen lingkungan menempati dan melakukan proses, sehingga antara ruang dan komponen lingkungan merupakan sutu kesatuan ${ }^{10}$ dengan semua benda, daya, keadaan, makhluk hidup termasuk manusia dan perilakunya, yang mempengaruhi kelangsungan perikehidupan dan kesejahteraan. ${ }^{11}$

${ }^{8}$ Armour, A\& R.Lang. (1975). Environmental Planning Resource book Land. Canada: Directorate Environment Montreal dan Soerjani, dkk. (1997). Pembangunan dan Lingkungan. Meniti Gagasan dan Pelaksanaan Sustainable Development. Jakarta: Yayasan Institut Pendidikan dan Pengembangan Lingkungan

${ }^{9}$ Badan Pusat Statistik, Statistik Lingkungan Hidup Indonesia 2016, (Jakarta: BPS, 2016), h. 3

${ }^{10}$ Pramudiya Sunu, Melindungi Lingkungan dengan Menerapkan ISO 14001, (Jakarta: Grasindo, 2001), h. 10

${ }^{11}$ N.H.T. Siahaan, Hukum Lingkungan dan Ekologii Pembangunan, (Jakarta; Erlangga, 2004), h. 4 . 
Lantas, sejauhmana manusia dapat memperoleh kenyamanan atau kesejahteraan yang didapat dari alam dengan segala variannya, itu amat bergantung pada usaha manusia mengatur dan menempatkan komponen lingkungan itu secara proporsional, karena berubahnya sebuah alam ke arah yang menguntungkan atau merugikan yang biasa disebut dengan bencana itu dipengaruhi dua hal, yaitu: pertama, akibat bencana yang memang telah ditetapkan dan ditakdirkan secara alami terjadi sesuai siklus perkembangan dan perjalanan waktu. Kedua, bencana akibat ulah tangan manusia sendiri yang tidak bertanggung jawab, hanya mementingkan kebutuhan sesaat. Terdapat empat kriteria dasar dalam membangun pemahaman agama (Al-Qur'an) yang harus dipahami berkaitan dengan aspek ekologi dan lingkungan hidup. Kriteria tersebut, antara lain: taskhir (penundukan), 'abd (penghambaan), khalifah (leadership) dan amanah (dipercaya). Faktor-faktor pemahaman hakikat awal tujuan dari penciptaan alam semesta dan manusia secara komprehensif dan berimbang, sehingga dapat memberikan penalaran yang baik mengenai relasi manusia dan lingkungan dalam hubungannya dengan keteraturan struktur alam ${ }^{12}$ adalah segala sesuatu yang berada di sekitar manusia, baik binatang, tumbuh-tumbuhan, maupun benda-benda tak bernyawa sebagai sebuah kesatuan jaringan struktur bumi.

\section{Jaringan Struktur Bumi Menua}

G. Brent Dalrymple, yang dimuat dalam jurnal: Special Publications, Geological Society of London dalam buku berjudul: The age of the Earth in the twentieth century: a problem (mostly) solved menyebutkan bahwa Bumi yang dipijak atau didiami, ini

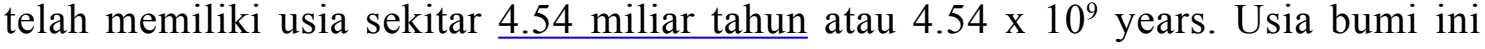
ditetapkan menggunakan penanggalan radio metrik meteorit sesuai usia bebatuan tertua berdasarkan temuan sampel benda-benda dari bulan. Sebagai perbandingan, adalah matahari yang telah berusia sekitar 4.57 miliar tahun, 30 juta tahun lebih tua dari bumi. Pada tahun 1862, fisikawan William Thomson yang dikutip England, P. dkk ${ }^{13}$ mengeluarkan perhitungan bahwa usia Bumi adalah 20 juta hingga 400 juta tahun. Secara fisik, data di atas menunjukkan kondisi bumi, tempat manusia hidup, juga makhluk Allah lainnya berkembang biak, nampaknya sudah mengalami masa penuaan, masa tua renta yang berati menurunnya daya tahan anatomi struktur bumi dalam mempertahankan eksistensinya akibat perubahan alamiah yang dialaminya dan berakibat pada terjadinya berbagai perubahan sama seperti makhluk lainnya.

Memasuki tahun-tahun berjalan, sejumlah prediksi menakutkan kembali terdengar. Meski tak didasari bukti dan fakta, beberapa orang meramalkan bahwa kehidupan di muka bumi bisa berakhir. Hal yang dijadikan petunjuk adalah fenomena Super Blood Moon. Gabungan antara supermoon dan blood moon yang akan terjadi pada suatu waktu yang tidak pasti. Tak hanya itu, klaim kiamat juga mengemuka setelah adanya pemberitaan munculnya asteroid atau batu angkasa raksasa yang konon bisa mengancam bumi dan kehidupan manusia di dalamnya, meski dugaan itu sudah dibantah mentah-mentah oleh NASA. Kiamat diyakini sebagai akhir dari kehidupan. Namun, selain peristiwa yang tak bisa ditebak kapan datangnya itu, ada sejumlah faktor lain yang juga mampu

\footnotetext{
${ }^{12}$ Misbahkhunur, M.Si., Tanggung Jawab Terhadap Alam Dan Lingkungan, modul 8 universitas brawijaya, h. 221-240

13 England, P. dkk "John Perry >s neglected critique of Kelvin $>$ age for the Earth: A missed opportunity in geodynamics". GSA Today. 2007, Vol. 17, No. 1, h. 4-9
} 
mengancam keberadaan manusia, ${ }^{14}$ berikut diprediksi yang dapat menghancurkan bumi dan peradaban manusia, antara lain: Supervolcano, Letusan gunung di Siberia 252 juta tahun lalu dikabarkan pernah menyapu bersih 95 persen kehidupan di Bumi. Juga, letusan Gunung Toba yang terjadi kira-kira 74.000 tahun lalu. Manusia banyak yang percaya bahwa ledakan besar berikutnya akan terjadi, meski semua itu belum bisa diramalkan kepastian terjadinya. Misalnya, gunung api supervolcano diduga akan meletus yang akan terjadi di Taman Nasional Yellowstone, Amerika Serikat yang memiliki kemampuan memuntahkan batu dan abu lebih dari 1.000 kilometer kubik dalam satu waktu, bahkan 2.500 kali lebih banyak dari Gunung api St. Helens yang meletus pada 1980 dan menelan korban jiwa 57 orang. Para ilmuwan berasumsi bahwa material vulkanik gunung api Yellowstone dapat menutup sebagian besar kawasan Amerika Serikat dan bahkan menenggelamkan Bumi ke dalam kondisi Dingin yang Akut. Majalah harian New York Times, menurunkan berita bahwa erupsi dahsyat Yellowstone terjadi pada 631.000 tahun lalu, dan letusan super itu telah «mencakar» planet bumi setiap 100.000 tahun yang menjalar ke gunung berapi lainnya di dunia, membuat para ilmuwan bergeliat dari tidur panjangnya. Menurut NASA letusan luar biasa kala itu dapat menyebabkan berakhirnya peradaban manusia bila terjadi lagi di abad-abad berikutnya.

Pemanasan global, menurut para ahli, menunjukkan adanya kenaikan suhu Bumi sebesar enam persen saja, itu sudah cukup untuk memberi efek perubahan di dunia ini ke arah yang lebih buruk. Setiap tahun, para ahli selalu melaporkan bahwa ada es yang mencair di kutub utara dan selatan. Akibat mencairnya lapisan es secara masif menyebabkan permukaan laut global naik sekitar sepuluh inci (setara 7,6 milimeter) per tahun. Menurut hasil penelitian yang dimuat di jurnal Nature, dari 1992 hingga 2011, Antartika akan kehilangan hampir 84 miliar ton es per tahun pada Perang Dunia III, banyak ilmuwan mengkhawatirkan skenario perang nuklir yang akan terjadi dalam waktu dekat, misalnya bila ketegangan yang terjadi di laut cina selatan, yang melibatkan kekuatan senjata nuklir antara blok Amerika Serikat di satu sisi dan blok Cina pada sisi lain. Terjadinya peperangan dan meningkatnya eskalasi suhu politik merupakan salah satu faktor pecah dan meledaknya perang dunia. Bahkan terdapat sejumlah tempat yang dijadikan penyimpanan nuklir. Jika berlanjut dan menggila perang nuklir antara dua negara super adidaya (AS dan Cina) dewasa ini, tentu efeknya akan membuat suhu Bumi turun dan mengancam populasi manusia yang dilatarbelakangi terlebih dahulu punah oleh adanya berbagai sebab kerusakan lingkungan hidup terjadi.

\section{Penyebab Kerusakan Lingkungan Hidup}

Merujuk pada Undang-Undang No. 24 Tahun 2007 yang intinya bahwa bencana alam adalah serangkaian peristiwa yang mengancam dan mengganggu stabilitas kehidupan dan penghidupan masyarakat, baik oleh faktor alam mapun perbuatan tangan-tangan manusia, seperti: kerusakan lingkungan, kerugian harta benda, dan kemalangan serta dampak negatif psikologis ${ }^{15}$ lainnya. Paling tidak ditemukan dua faktor terjadinya kerusakan lingkungan, ${ }^{16}$ yakni faktor internal dan faktor eksternal. Faktor ineternal

\footnotetext{
${ }^{14}$ Laman scotlandnow, kamis (13/12/2018)

${ }^{15}$ BNPD, Pengetahuan Defenisi dan Jenis Bencana, dalam http://www.bnpd.go.id/

${ }^{16}$ Pramudiya Sunu, Melindungi Lingkungan dengan Menerapkan ISO 14001, (Jakarta: Grasindo, 2001), h. 30
} 
adalah kerusakan yang berasal dari bumi/alam itu sendiri. Kerusakan lingkungan karena faktor internal tidak bisa dihindari, karena merupakan proses alam seperti gempa bumi, letusan gunung berapi, badai, banjir besar dan sebagainya. Faktor eksternal adalah kerusakan yang berasal dari perilaku manusia untuk meningkatkan kualitas dan kenyamanan hidupnya tanpa mengindahkan kelestarian lingkungan seperti pencemaran udara, air, atanh dan suara akibat industrialisasi, kebakaran hutan karena perluasan perkebunan, dan sebagainya. Dari pengertian ini dapat menggiring pengetahuan seseorang terkait peristiwa bencana alam yang terbagi menjadi tiga poin penting yaitu: pertama, bencana yang diakibatkan oleh alam sendiri, yaitu bencana yang penyebab terjadinya tidak dipengaruhi oleh ulah tangan manusia seperti gempa bumi, tsunami, kekeringan, angin topan, dan lain-lain. Kedua, bencana yang diakibatkan oleh sebuah peristiwa atau serangkaian kejadian yang datang dari faktor kekeliruan dan ketidaktahuan manusia (humman error) yang antara lain bisa berupa: gizi buruk, stunting, wabah penyakit, kecelakaan transportasi, kecelakaan industri, dan kejadian luar biasa, seperti fandemi covid-19. Ketiga, bencana sosial yang diakibatkan oleh sebuah peristiwa atau serangkaian kejadian yang dipicu oleh persepsi, sikap, dan tindakan manusia yang dapat berupa konflik sosial antar kelompok atau antar komunitas masyarakat, teror, sabotase, dan SARA. ${ }^{17}$

Sementara dalam perspektif Al-Qur'an, bencana dapat diperserupakan pada beberapa diksi, di antaranya yang paling mendasar maknanya adalah al-Baliyyah atau al-Dahr yang berarti kondisi yang tidak disukai, semisal: kemalangan, kemiskinan, keterbelakangan, kelaparan, tertindas, terjajah ${ }^{18}$ sebagaimana menimpa sebagian umat Islam seperti di Gaza, Palestina dan di negara-negara yang entitas muslimnya minoritas. Bencana di sini mempunyai beberapa sifat yaitu bencana yang bersifat hissi (inderawi) di mana akan banyak orang yang mampu melihat serta mengalaminya dan bencana yang bersifat ruhi atau ma'nawi yang mana bencana seperti ini akan lebih mengarah kepada hal yang bersifat subjektif karena hanya satu orang individu yang akan mengalami dan dapat merasakan serta menilainya. Bencana yang termasuk dalam kategori ini di antaranya adalah tercabutnya rasa malu ketika berbuatan salah, terjadi degradasi iman dari dalam hati seseorang, ilmu yang tidak bermanfaat bahkan tidak jarang digunakan untuk memanipulasi data dan fakta serta menipu orang lain demi meraup keuntungan pribadi sebanyak-banyaknya. Juga, bencana itu dapat berupa fisik yang diungkap dalam beberapa ayat Al-Qur'an sebagaimana akan dijelaskan pada ragam penafsiran ayat-ayat kerusakan lingkungan hidup oleh para ahli di bidang tafsir.

\section{RAGAM PENAFSIRAN AYAT KERUSAKAN LINGKUNGAN}

Kerusakan atau kebinasaan yang terjadi di dalam Al-Qur'an terkadang disebutkan atau diungkapkan dengan menggunakan diksi dan narasi yang berbeda-beda, akan tetapi maknanya tetap sama seperti kata halaka, sa'aa, dammara dan fasada

\section{Penafsiran Kata Halaka}

Istilah halaka dan semua derivasinya disebutkan dalam Al-Qur'an seluruhnya ada 68 kali, namun kesemuanya itu tidak menunjukkan arti kerusakan lingkungan

\footnotetext{
${ }^{17}$ Eko Prasetio, Jurnal AL-DZIKRA, Volume 12, No. 1, Juni Tahun 2018, h. 122

18 Muhammad Alfatih Suryadilaga, Pemahaman Hadits Tentang Bencana (Sebuah Kajian Teologis Terhadap Hadits-Hadits Tentang Bencana), dalam Essensia Vol. XIV No. 1 April 2013, 83102
} 
sebagaimana penjelasan Imam al-Ashfani bahwa istilah halaka bisa dibagi dalam empat makna, yakni: hilangnya sesuatu dari diri seseorang, menghabiskan harta benda, kerugian atau kemadharatan, kehancuran berupa; kematian atau meninggal dunia yang fana atau lawan dari baqa. Kata al-hulk dengan huruf ha' yang berharakat dhamah, artinya menghancurkan. Sedangkan at-tahlukah artinya sesuatu yang dapat mengakibatkan kehancuran seperti pada surat al-Baqarah ayat 195

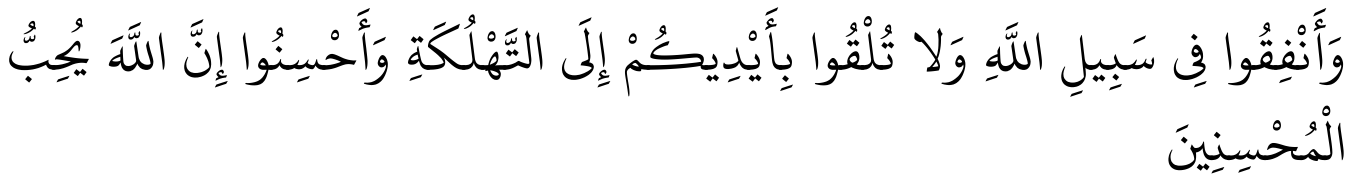

Aslam Abu Imran menceritakan bahwa seorang lelaki dari kalangan Muhajirin ketika terjadi peperangan di Qustantiniyah (Konstantinopel), ia maju sendirian melabrak barisan musuh hingga dapat menerobos dan memporak-porandakannya (lalu ia kembali lagi ke barisan), sedangkan bersama kami ada Abu Ayyub al-Ansari. Orang-orang berkata, «dia telah menjerumuskan dirinya ke dalam kebinasaan», lalu Abu Ayyub menjawab, «kami lebih mengetahui tentang ayat ini, sesungguhnya ayat itu diturunkan berkenaan dengan kami ketika menemani Rasulullah dan ikut bersama beliau dalam semua peperangan, membantu dengan tenaga, harta, dan pikiran. Setelah Islam berkembang dan tersebar luas, kami (orang-orang Anshar) pun berkumpul mengadakan reuni seraya berkata: Allah telah memuliakan kita karena menjadi sahabat Nabi SAW. dan berjuang bersama-sama beliau sehingga Islam tersebar dan para pemeluk agama Islam menjadi golongan mayoritas. Dedikasi dan loyalitas hidup kita diprioritaskan hanya untuk kepentingan Nabi SAW daripada keluarga, harta benda, dan anak-anak kita. Setelah tidak ada lagi peperangan, kami pun kembali kepada keluarga dan anak-anak serta tinggal bersama mereka, lalu turunlah surat al-Baqarah ayat 195 yang artinya: «Dan belanjakanlah (harta benda kalian) di jalan Allah, dan janganlah kalian menjatuhkan diri kalian sendiri ke dalam kebinasaan. Maka kebinasaan itu akan terjadi apabila kami bermukim mengurusi keluarga dan harta benda, sedangkan jihad kami tinggalkan.» ${ }^{19}$ Jadi, makna halaqa dalam konteks ayat ini adalah lalai, tidak mau berinfak atas harta yang telah dianugerahkan Allah kepadanya, mengabaikan prinsip-prinsip jihad fie sabilillah, lebih mementingkan selera dan kenikmatan duniawi, mengumpulkan harta kekayaan dengan cara tidak terpuji, itulah kebinasaan sebagaimana hal ini dipertegas dalam bahasan penafsiran kata sa'aa.

\section{Penafsiran Kata Sa'aa}

Term sa'aa dengan seluruh kata jadiannya di dalam Al-Qur'an dijelaskan ada 30 kali yang digunakan sebagai kata pinjaman (isti'arah) untuk menunjukkan kesungguhan dalam melaksanakan suatu perbuatan/aktivitas kerja, baik terpuji maupun tercela. Akan tetapi pemakaian kata yang terbanyak adalah menunjuk perbuatan atau usaha terpuji. Dari beberapa makna terminologi bahwa kata sa'aa yang terdapat di dalam banyak ayat, hanya ada beberapa ayat saja yang bisa mengarah kepada makna perusakan lingkungan, di antaranya:
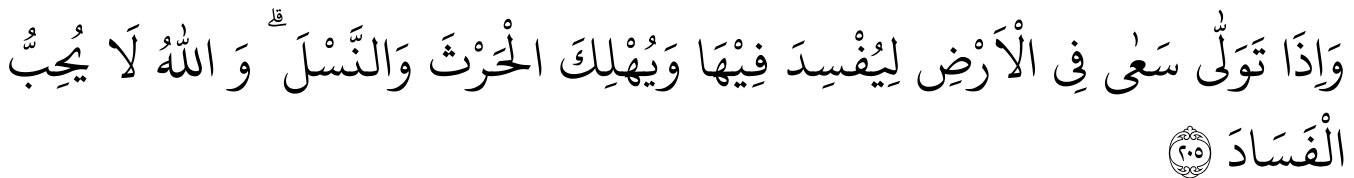

${ }^{19} \mathrm{http} / /$ www.ibnukatsironline.com/2015/04/tafsir-surat-al-baqarah-ayat-195.html 
Dan apabila dia (orang kafir) berpaling (dari engkau), dan berusaha untuk berbuat kerusakan di bumi, serta merusak tanam-tanaman juga ternak, padahal Allah tidak menyukai kerusakan. [QS. al-Baqarah [2]: 205]. ${ }^{20}$

Kata tawallā bermakna kembali dan berpaling, atau ia memiliki kekuasaan. Sementara kata al-harth berarti tanaman dan an-nasl berarti hewan. ${ }^{21}$ Yang mana kontek al-nasl ini juga dapat dipahami dalam artian wanita dan anak-anak. ${ }^{22}$ Hal ini senada dengan penjelasan tafsir al-Aisar yang menyatakan bahwa Allah Ta'ala hendak menginformasikan kepada Rasul-Nya dan orang-orang yang beriman tentang kondisi orang-orang munafik. Di mana Allah berfirman yang artinya: dan di antara manusia terdapat seorang laki-laki munafik yang bicaranya sangat menarik. Jika berkata maka akan membuat orang yang mendengarkannya kagum kepadanya karena keindahan tutur kata, intonasi dan gaya bahasanya yang indah, terutama ketika ia membicarakan masalah-masalah kehidupan dunia. Akan tetapi ketika berbicara tentang persoalanpersoalan akhirat maka pasti ia tidak akan tahu dan tidak punya keinginan untuk memahami dan membicarakannya. Hal itu mereka lakukan karena kekafirannya kepada allah dan Rasul-Nya. Sesugguhnya Allah Ta'ala menyaksikan bahwa Rasulullah percaya terhadap perkataan orang-orang munafik itu dan Allah mengetahui pula bahwa mereka itu mengaku orang beriman dan mencintai Rasul-Nya, serta Allah Ta'ala menyaksikan apa yang mereka perbuat. Dan jika ia beranjak dari majelis Rasulullah, mereka pun menjauh $^{23}$ dari Rasul lalu berjalan di muka bumi dengan melakukan kerusakan, seperti menghancurkan tanam-tanaman dan binatang ternak serta berbuat berbagai tindakan kriminalitas. Perbuatan seperti ini, tentu tidak disukai Allah Ta'ala dan Dia sangat membencinya serta membenci pula orang yang melakukannya. Ekses dari tindakannya itu, maka hujan pun tidak turun, terjadi kemarau dan tanaman layu menguning, bumi kering dan gersang, hewan-hewan mati, serta terputuslah keturunan dan pekerjaannya, lalu Dia menghancur binasakan mereka dengan sehancur hancurnya sebagaimana dijelaskan dalam penafsiran kata dammara berikut.

\section{Penafsiran Kata Dammara}

Term lafadz dammara dan seluruh kata jadiannya terdapat dalam 8 ayat di dalam Al-Qur'an. Kata dammara berarti menghancurkan, sedangkan kata at-tadmīr artinya memasuki sebuah kehancuran yang akan menimpa pada sesuatu, seperti dalam firman Allah berbunyi:

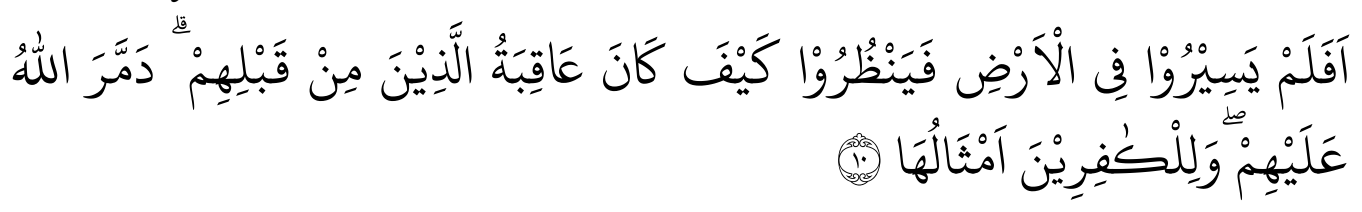

Pernahkan mereka mengadakan perjalanan di bumi dan memperhatikan bagaimana (akibat) kesudahan orang-orang sebelum mereka yang telah dibinasakan oleh Allah. [QS. Muhammad [47]: 10].

${ }^{20}$ Al-Raghib Al-Ashfani, Kamus Al-Qur'an, Jilid 3, terj.: Ahmad Zaini Dahlan, (Jakarta: Pustaka Khazanah Fawaid, 2017), h.. 880-883. DEPAG, Al-Qur'an dan Terjemahan, (Bekasi: Darul Haq, 2014), h. 32

${ }^{21}$ Quraish Shihab, Tafsir Al-Misbah, Volume I, (Jakarta: Lentera Hati, 2000), h.. 417

${ }^{22}$ Ibnu Katsir, Tafsri Al-Qur'an Al- 'Adzim, (Aplikasi), h. 128

${ }^{23}$ DEPAG, Al-Qur'an dan Terjemahannya, (Bekasi: Darul Haq, 2014), h.. 379 
Narasi ayat di atas merupakan sebuah pertanyaan inkari, apakah orang-orang kafir yang mendustakan Allah dan rasul-Nya tidak pernah mengadakan perjalanan di bumi di mana terdapat peninggalan umat terdahulu sehingga dapat memperhatikan bagaimana kesudahan dan akibat yang diderita oleh orang-orang yang mendustakan rasul sebelum mereka seperti yang menimpa pada umat nabi Nuuh, Penduduk Ra's, Tsamud dan 〈Ad, balatentara Firaun, Iram dan kaum Nabi Luth (surat Qāf [50]:12-14). Fisik dan jiwa mereka dibinasakan termasuk harta dan anak keturunannya, sehingga bagi orang-orang kafir, kapan dan di mana pun akan menerima nasib serupa itu, seperti makna ayat 36 surat al-Furqan yang berbunyi:

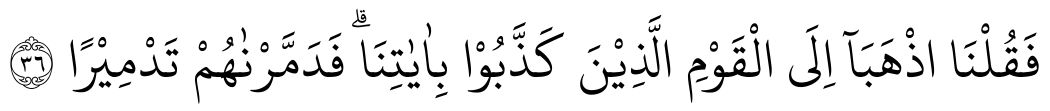

"Pergilah kamu berdua kepada kaum yang mendustakan ayat-ayat Kami," lalu mereka dibinasakan se-hancur-hancurnya. (QS. al-Furqān [25]: 36).

Secara eksplisit, khitab ayat tersebut di atas menjelaskan maknanya bahwa Allah memerintahkan nabi Musa dan Harun As, "pergilah kamu berdua kepada kaum yang mendustakan ayat-ayat Kami (Firaun dan balatentaranya) dan yang dimaksud kaum pendusta adalah bangsa Koptik, Firaun dan kaumnya, lalu keduanya berangkat ke negeri Mesir menemui Firaun, akan tetapi mereka mendustakannya, maka mereka pun dihancurkan dengan cara ditenggelamkan ke dalam lautan, sebagaimana firman-Nya, "maka Kami membinasakan mereka sehancur-hancurnya, akibat pembangkangannya terhadap perintah Allah dan penolakannya atas ajakan para rasul-Nya, lalu mereka ditenggelamkan ke dasar lautan (laut merah) seperti dijelaskan dalam uraian penafsiran kata fasada berikut.

\section{Penafsiran Kata Fasada}

Istilah Al-Qur'an yang terkait langsung dengan kerusakan adalah kata fasada yang terdapat di dalam Al-Qur'an dengan segala bentuk kata jadiannya yang terulang sebanyak 50 kali. Ruang lingkup makna fasada ternyata memiliki cakupan yang sangat luas, melingkupi aspek jiwa/rohani, badan/fisik, dan apa saja yang menyimpang dari keseimbangan yang semestinya. ${ }^{24}$ Antonim kata fasad adalah saleh yang secara umum keduanya terkait dengan sesuatu yang manfaat dan tidak berguna. Artinya, apa saja yang tidak membawa manfaat baik secara individu maupun sosial dimasukkan ke dalam kategori fasad. Begitu juga sebaliknya, apapun yang membawa manfaat dapat dikelompokkan ke dalam kategori saleh (baik), firman Allah.

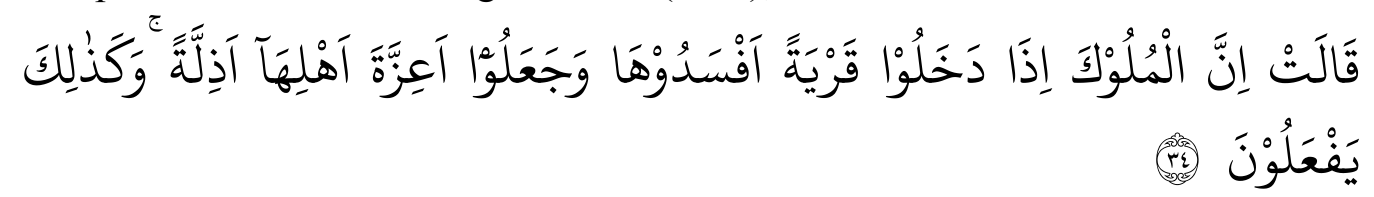

"Balqis berkata, "Sesungguhnya raja-raja apabila memasuki suatu negeri, niscaya mereka merusak (tanam-tanaman dan pepohonan), serta menghinadinakan penduduknya. Dan demikianlah yang akan mereka perbuat." (QS. alNaml [27]: 34).

Pada ayat sebelumnya Allah Ta'ala menceritakan peristiwa nabi Sulaiman As ketika mengirimkan surat kepada ratu Balqis yang berisi ajakan untuk menyembah Allah

${ }^{24}$ Al-Raghib Al-Ashfani, Kamus Al-Qur'an, Jilid 3, terj.: Ahmad Zaini Dahlan, (Jakarta: Pustaka Khazanah Fawaid, 2017), h.. 62 
dan memberitahukan bahwa ia adalah seorang nabi utusan Allah. Kemudian Balqis membacakan surat itu di hadapan para pembesar kerajaannya dan meminta saran dari mereka mengenai langkah apa yang harus ia ambil menanggapi surat nabi Sulaiman As tersebut, apakah menerima atau menolak dengan cara memeranginya. Lalu pada, akhirnya Ratu Balqis pun memutuskan untuk mengirim utusan terlebih dahulu dengan membawa hadiah untuk diseerahkan keapda nabi Sulaiman As. Apabila hadiah itu berarti, berarti Sulaiman seorang raja, dan tentu akan menindas dan berbuat kerusakan sebagaimana potongan ayat berikut:

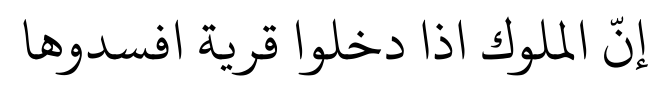

Ibnu Abas mengatakan bahwa yang dimaksud ayat di atas ialah bahwa rajaraja apabila memasuki suatu negeri dengan cara paksa (merampas), niscaya mereka akan berbuat kerusakan, ${ }^{25}$ menghancurkan bangunan-bangunan dan harta-harta serta menghinakan penduduknya dengan menawan dan mengusir dari kampung halamannya ataumembunuhmereka secarakejam. ${ }^{26}$ Sang Ratu setelah mempertimbangkan segala segi, dan memperhatikan pula isi surat dan cara penyampaiannya, maka ia pun berkesimpulan yang cenderung untuk tidak berperang dan sekaligus mengabaikan pendapat para penasihatnya sebagaimana terungkap jawaban para penasihatnya, yaitu: sesungguhnya raja-raja apabila memasuki suatu negeri, niscaya mereka membinasakannya, tak terkecuali Sulaiman As dan tentaranya. Karena itu, Ratu Balqis sangat memahami dan menyadari hal itu, akan mengalami kekalahan bila terjadi peperangan. ${ }^{27}$ Al-Hasan alBasri mengatakan para penasihat dan pembesar negeri Saba menyerahkan keputusan akhir kepada Ratu setelah mereka menyampaikan pendapatnya. Ratu memiliki hak prerogatif dengan keluasan wawasan, pandangan dan pengetahuan perihal pribadi nabi Sulaiman As setelah memahami dengan keyakinan penuh ('ain al-yaqīn) melalui wasilah surat yang dibawa burung hud-hud, yang menunjukkan suatu perkara luar biasa dan sangat menakjubkan. Ratu Balqis berkata kepada kaumnya, "sesungguhnya aku merasa khawatir akan mengalami kekalahan bila memeranginya, kemudian Sulaiman As balik membalas serangan dengan kekuatan penuh, menggunakan bala tentaranya yang terdiri dari manusia, jin, dan burung-burung, maka sudah pasti negeri Saba akan hancur binasa, luluh lantak diratakan dengan bumi. Lalu, Balqis berucap seperti disitir dalam firman-Nya: "dan menjadikan hina penduduknya yang mulia" (al-Naml: 34)

Melalui pertimbangan yang matang demi kemaslahatan dan keselamatan diri dan rakyatnya, Ratu Balqis pun mengambil keputusan untuk berdamai, melalukan gencatan gencatan senjata melalui jalan diplomasi. ${ }^{28}$ Qatadah mengatakan bahwa alangkah cerdiknya Ratu Balqis di masa ia telah masuk Islam dan juga sewaktu masih musyrik. Pemberian hadiah pada lawan (musuh) adalah taktik perang untuk melunakkan hati lawan, maka Balqis pun melakukan hal yang sama pada nabi Sulaiman sebagaimana diceritakan Ibnu Abbas, jika Sulaiman itu mau menerima hadiah, artinya dia adalah seorang raja, boleh diperangi, tetapi jika menolak hadiah itu, maka dia seorang nabi, ikutilah dia oleh kalian". ${ }^{29}$ Sebab hadiah termasuk perkara yang dapat melahirkan kecintaan dan

${ }^{25}$ Ahmad Mustafa Al-Maraghi, Tafsir Al-Maraghi, Juz 19, (Semarang: Toha Putera, 1995), h. 254

${ }^{26}$ M. Quraish Shihab, Tafsir Al-Misbah, Volume I, (Jakarta: Lentera Hati, 2000), h.. 220.

${ }^{27}$ Ibnu Katsir, Tafsir Al-Qur'an Al- 'Adzim, (Aplikasi), h.. 8

${ }^{28}$ Ibnu Katsir, Tafsir Al-Qur'an Al- 'Adzim, (Aplikasi), h.. 9

${ }^{29}$ Ahmad Mustafa Al-Maraghi, Tafsir Al-Maraghi, h.. 255

124 | Al-Fanar: Jurnal Ilmu Al-Qur'an dan Tafsir 
menghilangkan permusuhan. ${ }^{30}$ Pernyataan Balqis ini memberikan pemahaman bahwa ifsad di sini memiliki arti merusak dengan cara membumi hanguskan apa yang tumbuh di negeri itu dan menjadikan penduduknya tak berdaya sertas kehilangan kemuliaan dan kehormatannya. Ayat-ayat lain yang memiliki makna sama dengan fasada dalam artian adanya ketidakteraturan adalah sebagaimana firman Allah berikut:

1. Fasada dalam arti tidak teratur

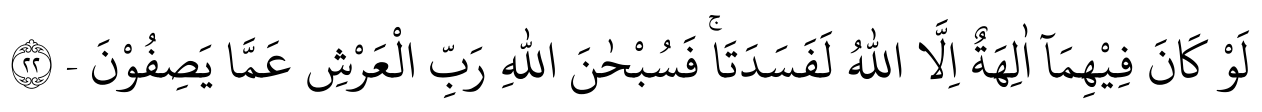

Seandainya pada keduanya (di langit dan di bumi) itu (massing-masing) ada tuhan selain Allah, maka pastilah keduanya akan binasa. Maka Maha suci Allah yang memiliki 'Arsy dari apa yang mereka sifatkan. (QS. al-Anbiya [21]: 22).

Pada ayat sebelumnya Allah Ta'ala mengingkari perbuatan orang-orang kafir yang menjadikan tuhan-tuhan selain-Nya sebagai sesembahan mereka, seperti; batu, emas, perak dan sebagainya. Allah Ta'ala melalui ayat di atas mengajukan pertanyaan ingkari, apakah mereka menjadikan tuhan-tuhan dari bumi itu dapat menghidupkan (orang yang mati)?" Maka, sudah barang tentu tuhan-tuhan yang dijadikan tandingan itu tidak akan pernah bisa menghidupkan sesuatu yang telah mati. Lalu, mengapa orang-orang kafir itu menjadikan mereka tandingan bagi Allah? ${ }^{31}$ Jadi, kata fasada di dalam ayat ini berarti tidak teratur. Artinya, bumi dan seluruh isinya akan menjadi rusak, hancur binasa. Secara epistimologis, bahwa seluruh isi jagad raya ini berjalan teratur sesuai kehendak Sang Pencipta. Matahari, bulan, bintang, dan seluruh planet di alam semesta bergerak sesuai garis edarnya secara tetap dan terus menerus, sehingga tidak terjadi kesalahan waktu dan route perjalanan siang dan malam. Demikian pula peredaran bintang-bintang di planet bumi yang menujukkan satu sama lain tidaka saling bersinggungan apalagi bertabrakan. Hal ini membuktikan bahwa yang melakukan pengaturan memang hanya satu, yaitu Allah Yang Maha Besar. Maka ayat ini menunjukkan sesuatu yang musykil adanya Tuhan yang berhak disembah selain Allah Ta'ala.

Kandungan surat al-Anbiya ayat 22 di atas menjelaskan bahwa orang-orang uamg menyekutukan Allah, itulah yang menyebabkan terjadinya kerusakan. Kezaliman dan ketamakan menyebar di mana-mana, dan maksiat sudah menjadi budaya, sehingga manusia tak lagi memperhatikan apa yang diharamkan oleh Allah dan apa yang dihalalkan. Implikasinya, terjadi banyak kerusakan di mana-mana, baik kerusakan lingkungan, mental, moral, atau bahkan sosial. Faktor-faktor itulah, yang menyebabkan Allah Ta'ala menurunkan azab, berupa macam-macam benaca, baik yang merusak alam dan mempengaruhi gaya hidup ataupun peperangan karena perebutan kekuasaan atau kesombongan manusia menolak kebenaran. Imam alMaraghi dalam tafsirnya menjelaskan kata fasada bermakna munculnya berbagai kerusakan di bumi sebagai dampak dari peperangan dan penyerbuan berupa tumpahan peluru kendali atau bom-bom dari pesawat-pesawat terbang, kapal-kapal perang. ${ }^{32} \mathrm{Ibnu}$ Katsir menegaskan, berkurangnya tanam-tanaman dan buah-buahan karena perbuatan maksiat yang dikerjakan penghuninya, ${ }^{33}$ menyebabkan terjadinya kerusakan di darat seperti kekeringan, paceklik, hilangnya rasa aman, kekurangan hasil laut dan sungai,

\footnotetext{
${ }^{30}$ Ahmad Mustafa Al-Maraghi, Tafsir Al-Maraghi, Juz 19, (Semarang: Toha Putera, 1995), h. 323.

${ }^{31}$ DEPAG RI, Al-Qur'an dan Terjemahannya, (Bekasi: Darul Haq, 2014), h. 348

${ }^{32}$ Ibnu Katsir, Tafsir Al-Qur'an al- 'Adhim, (Aplikasi), h.. 13.

${ }^{33}$ M. Quraish Shihab, Tafsir Al-Misbah, Volume 10, (Jakarta: Lentera Hati, 2000), h. 76
} 
disebabkan karena perbuatan manusia yang durhaka, sehingga Allah menurunkan sedikit bencana kepada mereka sebagian akibat dari perbuatan dosa dan pelanggaran mereka, agar mereka kembali ke jalan yang benar ${ }^{34}$ dan menjauhi perbuatan syirik yang selama ini mereka yakini bahwa Allah itu memiliki keturunan, mahasuci Allah dari apa yang mereka persekutukan, sebagaimana dijelaskan pada uraian kata fasada beramakna syirik.

\section{Fasada dalam arti Syirik}

Kata fasada dalam artian musyrik atau mempersekutukan dengan menganggap bahwa Allah memiliki keturunan dijelaskan dalam beberapa ayat antara lain firman Allah berikut:

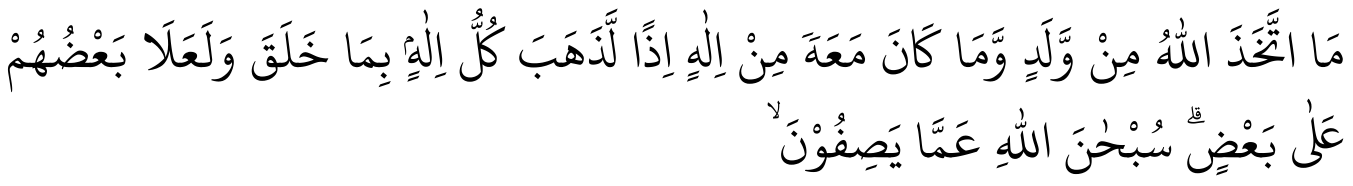

"Allah tidak mempunyai anak dan tidak ada tuhan (yang lain) bersama-Nya (sekiranya tuhan banyak), maka masing-masing tuhan itu akan membawa makhluk apa (makhluk) yang diciptakannya, dan sebagian dari tuhan-tuhan itu akan mengalahkan sebagian yang lain. Mahasuci Allah dari apa yang mereka sifatkan itu." [QS. al-Mu'minun: 91]. ${ }^{35}$

\section{Fasada dalam arti Merusak Ekosistem}

Makna fasada yang berati bencana selain akibat perbuatan syirik, juga dapat berbentuk bencana bersifat fisik akibat perbuatan tangan-tangan manusia merubah ekosistem alam sebagaimana dapat disimak pada surat al-Rum/30: 41 sebagai berikut

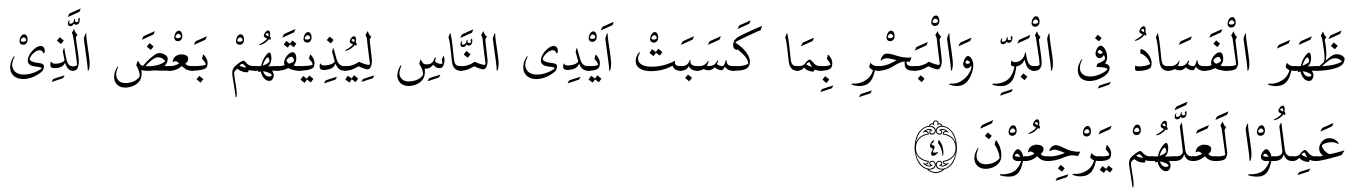

"Telah tampak kerusakan di darat dan di laut disebabkan karena perbuatan tangan manusia, Allah menghendaki agar mereka merasakan sebagian dari (akibat) perbuatan mereka, agar mereka kembali (ke jalan yang benar) "36. (QS. al-Rum/30: 41).

Ibnu Abbas mengatakan bahwa al-Barru adalah Padang sahara, ${ }^{37}$ daratan tempattempat yang dihuni oleh kabilah-kabilah, kota-kota dan perkampungan-perkampungan yang tidak memiliki sungai. Adapun makna al-bahru adalah sebutan untuk nama kotakota besar dan perkampungan-perkampungan yang memiliki sungai. Di mana kebiasaan orang-orang Arab menyebut kota-kota besar itu dengan sebutan lautan, mengingat kawasannya yang luas dan kepadatan penduduknya seperti lautan. Di dalam kitab tafsir al-Maraghi dijelaskan bahwa al-bahru adalah sebutan untuk kota-kota besar. ${ }^{38}$ Dan kebiasaan orang-orang Arab menyebut kota-kota besar dengan lautan, mengingat

\footnotetext{
${ }^{34}$ DEPAG, Al-Qur'an dan Terjemahannya, (Bekasi: Darul Haq, 2014), h.. 3

${ }^{35}$ Ibnu Katsir, Tafsir Al-Qur'an Al- 'Adzim, (Aplikasi), h.7

${ }^{36}$ Ibnu Katsir, Tafsir Al-Qur'an Al- 'Adzim, (Aplikasi), h. 8

${ }^{37}$ Ahmad Mustafa Al-Maraghi, Tafsir Al-Maraghi, Juz 19, (Semarang: Toha Putera, 1995), h.

${ }^{38}$ Ibnu Katsir, Tafsir Al-Qur'an Al- 'Adhim, (Aplikasi), h.. 13
} 100

126 | Al-Fanar: Jurnal Ilmu Al-Qur'an dan Tafsir 
kawasannya yang luas dan kepadatan penduduknya seperti lautan. ${ }^{39}$ Menurut ulama lainnya al-barr adalah daratan dan yang dimaksud al-bahr adalah lautan.

Kerusakan di muka bumi ( fasad $f i$ al-ardh) adalah terjadinya peperangan dan berkembangnya syahwat binatang yang mengakibatkan merosotnya kehidupan dan timbulnya dekadensi akhlak. ${ }^{40}$ Hal ini tentunya perlu dicarikan solusi memperbaiki dan meng-ișlah seraya mendekatkan diri, bertaubat dan beriman kepada Allah secara benar, beramal sholih dan meninggalkan perbuatan maksiat dan munkarat, akan tetapi kebanyak mereka tidak mengetahui dan tidak memahami. ${ }^{41}$ Larangan dalam ayat tersebut, biasa juga dimaksudkan untuk hal-hal yang akan menyebabkan kerusakan seperti membuka rahasia umat muslim kepada kaum kafir, kemudian menyuruh kaum kafir itu membujuk umat Islam agar tidak mengikuti nabi Muhammad, firman Allah dalam surat al-Baqarah/2: 11-12

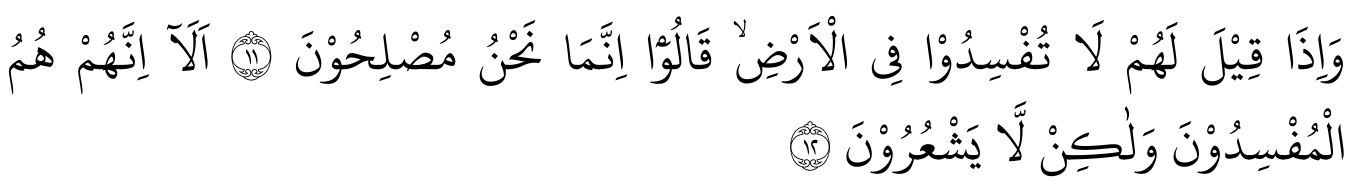

"Dan apabila dikatakan kepada mereka: "janganlah berbuat kerusakandi muka bumi! Mereka menjawab: "Sesungguhnya kami justru orang-orang yang melakukan perbaikan." Ingatlah, sesungguhnya mereka itulah orang-orang yang membuat kerusakan, tetapi mereka tidak sadar. (QS. al-Baqarah [2]: 11-12).

Makna ayat di atas secara global memberitahukan tentang salah satu karakter orangorang munafik bahwa ketika ada orang yang beriman berkata kepada mereka, "janganlah kalian berbuat kerusakan ${ }^{42}$ di muka bumi dengan melakukan kemunafikan dan bersikap loyal terhadap orang-orang non muslim." Mereka pun menjawab, "sesungguhnya kami hanyalah berbuat kebajikan, ${ }^{43}$ " Allah Ta'ala menolak pengakuan bohong mereka, karena sesungguhnya justru merekalah yang berbuat kerusakan. Akan tetapi orangorang munafik itu tidak menyadari hal itu dikarenakan kekafiran mereka yang sudah menguasai hatinya, ${ }^{44}$ yang sama sekali tidak merasakan perbuatannya itu merusak karena telah terbiasa dilakukan dan telah menyatu dengan watak kepribadiannya. Intisari surat al-Baqarah ayat 22 di atas menggambarkan bahwa orang-orang munafik benar-benar perusak dan tentu saja perusakan yang banyak dan dilakukan berulangulang, karena jika tidak mereka tentu tidak akan dinamai perusak. Bentuk kata perusak ini menunjukkan kemantapan makna yang terkandung pada si pelaku, berbeda jika bentuk kata yang digunakan adalah kata kerja (merusak). Maka berdasarkan pada paparan penafsiran kata fasada tersebut, hikmah yang dapat diambil adalah: 1) Mencela pengakuan yang dusta, yang biasanya merupakan karakter orang-orang munafik. 2) Berbuat kemaslahatan di bumi dengan banyak beramal, meningkatkan ketaatan kepada Allah ta'ala dan Rasul-Nya. Sedangkan membuat kerusakan di bumi yaitu berbuat durhaka kepada Allah ta'ala dan Rosul-Nya. 3) Orang-orang yang berbuat kerusakan

\footnotetext{
${ }^{39}$ Ahmad Mustafa Al-Maraghi, Tafsir Al-Maraghi, Juz 19, (Semarang: Toha Putera, 1995), h.10

${ }^{40}$ Ibnu Katsir, Tafsir Al-Qur'an Al-'Adhim, (Aplikasi), h. 15

${ }^{41}$ Ahmad Mustafa Al-Maraghi, Tafsir Al-Maraghi, Juz 1, (Semarang: Toha Putera, 1995), h.. 84

${ }^{42}$ Abu Bakar Jabir Al-Jazairi, Tafsir Al-Qur'an Al-Aisar (Jakarta: Darus Sunnah, 2008), h.. 5758

${ }^{43}$ Ahmad Mustafa Al-Maraghi, Tafsir Al-Maraghi, Juz 1, (Semarang: Toha Putera, 1995), h.. 84

${ }^{44}$ M. Quraish Shihab, Tafsir Al-Misbah, Volume 1, (Jakarta: Lentera Hati, 2000), h... 102
} 
biasanya melegitimasi perbuatannya itu dengan alasan membangun atau memperbaiki bukannya merusak.

Analisis makna istilah-istilah halaka, sa 'sa, dammara dan fasad dapat dideskripsikan sebagai berikut; bahwa jika kata-kata itu berbentuk masdar dan berdiri sendiri, maka maknanya menunjukkan kerusakan yang bersifat hissi/fisik, seperti banjir, pencemaran udara, dan lain-lain. Jika berupa kata kerja bentuk masdar, namun sebelumnya diawali kata kerja, maka yang terbanyak menunjukkan arti kerusakan yang bersifat non-fisik, seperti kafir, syirik, munafik, dan semisalnya. Dengan demikian dapat dipahami bahwa kerusakan yang bersifat fisik pada hakikatnya merupakan akibat kerusakan yang bersifat non-fisik atau mental. Argumentasinya, bahwa ayat-ayat sebagai dasar makan fasada bisa diidentifikasi yang menunjukkan makna kerusakan lingkungan yang secara spesifik merupakan akibat langsung dari perilaku manusia, seperti illegal logging, pencemaran udara dan lain-lain. Dari sini dapat dilihat adanya korelasi positif antara kerusakan lingkungan dengan rusaknya mental atau keyakinan yang menyimpang. Oleh karena itu, kerusakan akidah memberikan kontribusi besar penyebab terjadinya kerusakan lingkungan. Parameter ini, tentunya bukan diukur dari benar atau salahnya akidah seseorang, akan tetapi dapat dilihat dari perilakunya. Artinya perilaku menyimpang, merusak, dan tidak bermanfaat, bisa dipahami sebagai cerminan rusaknya mental seseorang. Dengan demikian, Allah mendedikasikan untuk senantiasa menjaga bumi ini, jika perilaku penduduknya mencerminkan seorang muslih yaitu senantiasa berusaha mengembangkan kebajikan yang bersifat sosial yang memiliki dampak secara nyata dalam kehidupan kemanusiaan dan lingkungan hidup secara umum.

Substansi ayat-ayat Al-Qur'an terkait kerusakan alam raya yang diciptakan dan diatur Allah atas azas keseimbangan, jika terjadi kerusakan alam atau penyimpangan dari ketentuan, pastinya harus diyakini hal itu sebagai akibat dari perbuatan manusia baik langsung maupun tidak langsung, sebagaimana disebutkan Al-Qur'an secara eksplisit dengan redaksi bimā kasabat ayd an-nās, pada surat al-Rum ayat 41, ini jelas menunjukkan bukti-bukti yang kuat bahwa kerusakan lingkungan merupakan akibat ulah tangan-tangan manusia. Hanya saja, ada di antara para ahli tafsir yang berpendapat bahwa ayat itu bukan dalam konteks kerusakan alam, seperti penebangan pohon secara ilegal, membuang sampah sembarangan, pembuangan limbah industri yang tidak sesuai amdal, dan lain-lain. Mereka berpandangan bahwa kerusakan itu lebih diarahkan pada perilaku non fisik, seperti kemusyrikan, kefasikan, kemunafikan, dan segala bentuk kemaksiatan. Faktor kerusakan mental inilah sesungguhnya penyebab utama terjadinya kerusakan lingkungan dan kerusakan mental inilah yang terkadang mendorong seseorang melakukan perilaku-perilaku destruktif, baik yang bersifat langsung seperti illegal logging, mendirikan bangunan di tempat-tempat resapan air, membendung saluran sungai sehingga terjadi penyempitan lebar sungai, bahkan, peperangan seperti penafsiran ayat al-Naml ayat 34. Perbuatan melawan hukum, seperti: korupsi, suap, penyalahgunaan jabatan, arogansi kekuasaan, kejahatan kerah putih, dan lain-lain. Jika perilaku menyimpang yang terkait secara langsung atau tidak dengan kerusakan alam ini berlanjut secara terus menerus dan membudaya, maka di sinilah Allah bencanabencana alam yang bersifat alamiah akan terjadi. Untuk itu perlu ada terobosan penyelesaian secara konkret berdasarkan analisis berbasis Al-Qur'an, melalui korelasi ekologi dan kerusakan lingkungan dalam konteks keseimbang dan keberlanjutan secara proporsional dan profesional. 


\section{SOLUSI MENGATASI KERUSAKAN LINGKUNGAN}

Fakta kerusakan dan bencana berdasar ayat-ayat Al-Qur'an yang telah diuraikan di atas, sebenarnya terdapat beberapa solusi yang dapat ditawarkan untuk mengatasi dan menghentikan terjadinya kerusakan lingkungan berkelanjutan, yaitu melalui internalisasi tauhid, sadar hukum lingkungan hidup dan pengelolaan berbasis akhlak mulia yang berkelanjutan.

\section{Internalisasi Tauhid}

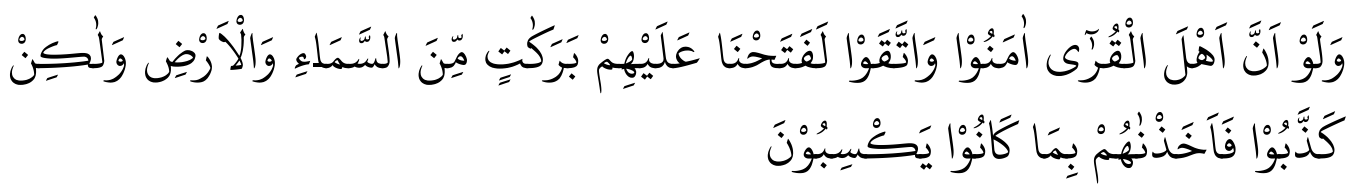

Seandainya penduduk negeri itu beriman dan bertakwa, pastilah berkahan dari langit dan bumi akan turun, akan tetapi mereka mendustakan, maka Allah siksa mereka”. ${ }^{45}$ (QS. al-A'raf [7]: 96).

Al-Qur'an memiliki konsep yang sangat jelas tentang hubungan manusia dengan lingkungan alam ini. Dalam pandangan Al-Qur'an lingkungan sebagai bagian tak terpisahkan dari nilai-nilai tauhid (keimanan) seseorang terhadap Tuhan. Artinya, perilaku manusia terhadap alam dan lingkungannya merupakan manifestasi dari ketauhidannya kepada Allah yang membebaskan manusia dari ketundukan kepada hawa nafsu dan penghambaan diri kepada makkluk. Nilai-nilai tauihid menjadikan setiap individu selalu merasa aman dan optimis, dan hal ini dapat mengantarkannya pada kondisi hidup tenang, damai dan selalu dapat berkonsentrasi dalam segala usaha yang dilakukannya. Oleh sebab itulah nilai-nilai tauhid selalu ditekankan dalam segala hal, ${ }^{46}$ yang dapat menumbuh kembangkan kesadaran bertanggung jawab dan memelihara manusia dari kecerobohan, ketidakadilan dan keangkuhan. Ketauhidan menjadi pendorong gerak dan dan aktivitas individu agar hidup lebih berhati-hati, tidak bertindak sewenang-wenang, dan tidak melampaui batas. Ketauhidan menjadikan penduduk suatu negeri dapat bekerja sama dalam kebaikan dan saling tolong-menolong untuk mengelola bumi serta menikmati hasilnya secara bersama-sama. Karena itu, semakin kokoh kerja sama yang dibangun dan ketenangan jiwa yang bersemayam dalam hati, maka semakin banyak pula hasil yang diraih dari alam raya ini, ${ }^{47}$ dan kedamaian yang selalu dirasakannya.

Faktor lingkungan hidup yang sangat kompleks dan universal, maka internalisasi nilai-nilai tauhid yang juga bersifat multidimensi menjadi sebuah keniscayaan yang harus dijadikan sebagai landasan pijakan dalam upaya mengatasi dan penyelamatan lingkungan dari kepunahan, akibat ulah segelintir manusia tak bermoral. Manusia harus kembali pada akar spiritualitasnya, yaitu tauhid. Karena hanya dengan pendekatan tauhid inilah pemanasan global bisa diatasi, termasuk pengehentiaan terjadinya pencemaran dan pengrusakan lingkungan hidup. Inilah nilai penting jati diri manusia

${ }^{45}$ M. Quraish Shihab, Tafsir al-Misbah, Volume 7, (Jakarta: Lentera Hati, 2000), h.. 183

${ }^{46}$ Sayyed Mohsen Miri, Prinsip-Prinsip Islam dan Filsafat Mula Sudra sebagai Basis Etis dan Kosmologis Lingkungan Hidup, dalam M. Mangunwijaya, dkk, ed, Menanam Sebelum KIamat: Islam, Ekologi, dan Gerakan Lingkungan Hidup, (Jakarta: ICAS, 2009), h.. 26

${ }^{47}$ M. Quraish Shihab, Tafsir al-Misbah, ,Volume 7,(Jakarta : Lentera Ahti, 2000), h.. 183 
untuk kembali kepada keimanan dan ketakwaan sebagai manifestasi tauhid yang merupakan fundamen utama solusi atas berbagai kerusakan lingkungan yang akibat hawa nafsu yang tak terkendali. Hanya orang-orang yang teguh ketauhidannya yang dapat mencegah tindakan-tindakan merusak yang menyebabkan kerusakan lingkungan, karena orang-orang yang bertauhid mereka amat sangat menyadari dan memahami hukum lingkungan hidup.

\section{Sadar Hukum Lingkungan Hidup}

Alam semesta menurut Imam Thabathaba'i bagaikan tubuh dalam keterkaitannya antara satu bagian dengan bagian yang lainnya. Apabila salah satu bagian dari anggota tubuh itu tidak berfungsi dengan baik, maka akan nampak dampak negatifnya pada bagian yang lain. Demikian halnya kesadaran terhadap lingkungan alam bahwa kehidupan manusia sangat bergantung padanya. Jika alam rusak maka manusia akan merasakan akibatnya. Sadar lingkungan berarti juga sadar akan peran dan fungsi manusia sebagai khalifah di muka bumi. ${ }^{48}$ Kesadaran lingkungan secara mendasar merupakan suatu ciri dan perbedaan antara manusia dengan makhluk hidup lainnya. Oleh karena itu manusialah yang sangat dominan dalam mengatasi masalah-masalah lingkungan, dan hal ini tergantung pada kesadaran manusia dalam memahami hukum lingkungannya. Kesadaran (awareness) mengandung pengertian mengetahui normanorma hukum atau bersikap atas nama hukum yang seharusnya, berdasarkan persepsi atau informasi valid dan faktual, sehingga ia tahu bagaimana seharusnya bersikap.

Kaitannya dengan lingkungan, seorang individu akan berkesadaran lingkungan apabila ia memiliki persepsi atau informasi tentang berbagai aspek lingkungan yang mensuportnya, dan kesadaran itu meningkat sejalan dengan makin banyaknya informasi yang diserap di dalam lingkungannya, terutama ketika mengatasi beragam masalah lingkungan yang dihadapi secara total, maka adanya suatu kesadaran akan merasa sangat penting arti sebuah lingkungan bagi kehidupan, terutama sekali hubungannya dengan kehidupan manusia yang bersifat sentral. Substansi posisi manusia sebenarnya memegang peranan sangat urgen dalam mengendalikan dan mengelola lingkungan, bahkan bisa juga sebaliknya, justeru menyebabkan terjadinya kerusakan lingkungan. Kesadaran lingkungan bagi masyarakat akan ditunjukkan dengan adanya respons dan sikap serta pemikiran positif terhadap lingkungan hidup yang terekspresikan dalam bentuk persepsi, emosi dan pemikiran, sehingga mampu memahami dan memikirkan sesuatu dengan kompreshensip dan berkesinambungan. Secara esensial, hakikat kesadaran lingkungan dapat dipahami sebagai suatu prasyarat untuk mengembangkan pengelolaan, pelestarian dan pemanfaatan lingkungan hidup sesuai dengan keberadaannya itu. Pengembangan lingkungan tanpa adanya kesadaran hukum lingkungan tentu tidak akan mencapai sasarannya, sebab pengembangan lingkungan, hanya akan lebih tepat dilakukan jika dilaksanakan berdasarkan pemahaman tentang hukum lingkungan secara konkret.

Sejauh ini terdapat hambatan dalam penegakan hukum lingkungan sebagaimana dijelaskan Andi Hamzah bahwa adanya hambatan atau kendala dalam penegakan hukum lingkungan yang ada di Indonesia, yaitu: ${ }^{49}$ (1) Hambatan yang bersifat alamiah

48 Kudwiratri Setiono, dkk., Manusia Kesehatan Dan Lingkungan: Kualitas Hidup Dalam Perspektif Perubahan Lingkungan Global, (Bandung: P.T. Alumni, 2007), h.. 97

${ }^{49}$ Hamzah, Andi. Penegakan Hukum Lingkungan. Edisi Revisi. (Jakarta: Sinar Grafika, 2005.) h. $53-54$

130 | Al-Fanar: Jurnal Ilmu Al-Qur'an dan Tafsir 
yaitu besarnya jumlah penduduk Indonesia yang tersebar di berbagai pulau dan memiliki beragam suku dan budaya sehingga memiliki persepsi hukum yang berbedabeda terutama mengenai lingkungan. (2) Kesadaran hukum masyarakat yang masih rendah oleh karena itu sangat diperlukan pemberian penerangan dan penyuluhan hukum secara luas. (3) Peraturan penanggulangan masalah pencemaran dan perusakan lingkungan, belum dilengkapi dengan peraturan pelaksanaannya sehingga tidak dapat difungsikan secara maksimal, misalnya penentuan pelanggaran yang dapat diterapkan sebagai pertanggung jawaban mutlak (strict liability) secara perdata. Memang, sudah ada ketentuan mengenai Analisis Mengenai Dampak Lingkungan (AMDAL) dan baku mutu, akan tetapi ketentuan tentang apa yang dimaksud dengan merusak lingkungan di dalam ketentuan pidana, itu belum ada. Begitu pula halnya dengan pengertian korporasi yang dapat dipertanggung jawabkan pidana. (4) Para penegak hukum belum memahami hukum lingkungan, hal tersebut drnrmsrnya dapat diatasi melalui berbagai macam pelatihan dan pendidikan. (5) Masalah dalam pembiayaan, dalam penanggulangan masalah lingkungan memerlukan biaya yang besar di samping penguasaan teknologi dan manajemen. Dalam peraturan lingkungan setidaknya terdapat dua sisi, yaitu: sisi pertama kaidah dan norma, sedangkan sisi kedua instrumen yang merupakan alat untuk mempertahankan, mengendalikan dan menegakan kaidah atau norma tersebut. ${ }^{50}$ Oleh sebab itu, diperlukan adanya kesamaan visi, misi dan persepsi dalam mengatasai dan menyelesaikan berbagai hambatan lingkungan sebagaimana uraian terebut di atas melalui tindakan pengelolaan lingkuan berbasis akhlak mulia.

\section{Pengelolaan Lingkungan Berbasis Akhlak}

Eksistensi alam dengan segala sumber dayanya diciptakan oleh Allah Ta'ala untuk memenuhi kebutuhan hidup manusia. Namun demikian, pemanfaatan sumber, tetap harus memperhatian ekosistem alam dan dilakukan dengan cara yang wajar (tidak boleh berlebihan) dan tidak pula diperkenankan hanya untuk memenuhi kebutuhan saat ini, dengan mengabaikan hak-hak generasi selanjutnya. Manusia dilarang menyalahgunakan wewenangnya untuk memanfaatkan dan atau merubah sumber daya alam, demi untuk memenuhi kepentingan tertentu sehingga hak pemanfaatannya bagi semua kehidupan menjadi berkurang bahkan nyaris hilang. Pengelolaan lingkungan merupakan salah satu kegiatan sekaligus tugas manusia dalam kehidupannya di muka bumi. Manusia diciptakan oleh Allah dengan sempurna. Ia diberi kelengkapan berupa akal pikiran, hati dan perasaan serta kelengkapan fisik biologis supaya dapat menjalankan fungsi dan tugasnya sebagai pengelola, pemelihara konservasi lingkungan alam dengan adil, tawasuth dan berakhlak sebagaimana diajarkan AlQur'an yang bersumber dari fungsi manusia sebagai khalifah seperti disebutkan di dalam surat al-Baqarah ayat 30 yang berbunyi sebagai berikut:

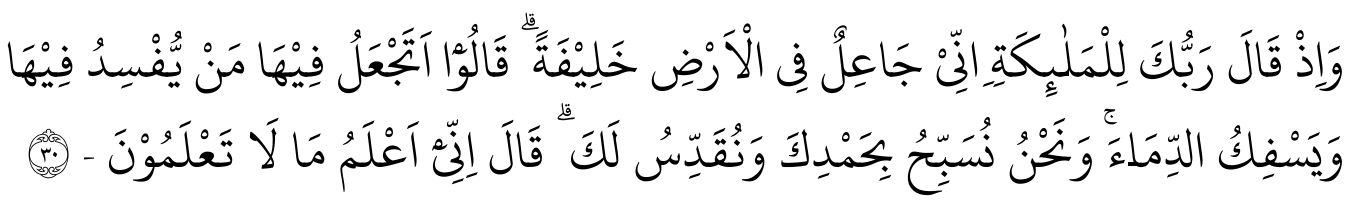

"Allah Ta'ala memaklumkan kepada para Malaikat bahwa Dia hendak menjadikan khalifah di muka bumi." Respons malaikat: "mengapa Engkau menjadikan (khalifah) yang akan berbuat kerusakan dan pertumpahan darah

${ }^{50}$ Saghara Luthfillah Fazari, Penegakan Hukum Lingkungan dan Pemanfaatan Ruang Udara. Jurnal Ekologi, Masyarakat \& Sains Volume 1, Nomor 1, 2020 ECOTAS http://journals. ecotas. org/ index. php/ ems 
di bumi ini. Padahal kami senantiasa mensucikan dan memuji Engkau?" Tuhan menjawab: "Sesungguhnya Aku mengetahui apa yang tidak kamu ketahui." (QS. al-Baqarah [1]: 30).

Manusia merupakan bagian dari alam semesta (kosmos) yang telah diciptakan Allah Ta'ala dan sebagai abdi-Nya. Manusia diberikan kekuasaan untuk memanfaatkan, mengolah, dan menjaga potensi alam semesta yang telah diciptakanNya (khalifatullah). Oleh karena itu membahas hubungan antara manusia, alam, dan Allah Ta'ala sebagai pencipta tidak dapat dipisahkan ${ }^{51}$ dari khalifah sebagai manadaris Allah dalam menjalankan pemeliharaan, pengelolaan dan pengawasan sumber daya alam bagi kesejahteraan setiap makhluk agar mencapai kesempurnaan sesuai tujuan perundang-undangan Allah. Tujuan dari aturan hukum Allah adalah untuk memelihara kemaslahatan manusia, sekaligus menghindari kerusakan (mafsadah), baik di dunia maupun di akhirat. Fakta menunjukan bahwa semua makhluk hidup di planet bumi ini sangat bergantung pada lingkungan alamnya, tidak terkecuali manusia. Hubungan simbiosis mutualisme (saling ketergantungan) antara manusia dengan lingkungan alam sekitar sangat menentukan kesinambungan antar keduanya terhadap keberlangsungan hidup (manusia dan alam) yang sangat bergantung pada sikap dan perilaku manusia itu sendiri sebagai khaalifah fi al-Ard (subjek atau pengelola) di bumi. Alasan itulah, yang menyebabkan manusia tetap tidak serta-merta dapat memperlakukan lingkungan alam sekehendak hatinya. Alam dengan lingkungannya, itu akan melakukan reaksi (perlawanan) terhadap manusia yang mengakibatkan kepunahan makhluk di bumi. Peran manusia sebagai subjek atas alam harus memahami antara melakukan konservasi dan pemamfaatan, yang tidak mengurangi kebergantungannya pada lingkungan alam. Ini artinya, melestarikan lingkungan, sama nilainya dengan memelihara kelangsungan hidup manusia itu sendiri dan semua makhluk yang eksis di alam ini. Sebaliknya, merusak lingkungan merupakan kejahatan besar dan serius terhadap keberlangsungan hidup makhluk Allah dan segala isinya, termasuk manusia. ${ }^{52}$

Merujuk kapasitas mandataris, maka manusia harus bisa merepresentasikan peran Allah terhadap alam semesta termasuk bumi seisinya dengan melakukan pengelolaan alam berbasis akhlak mulia, antara lain: memelihara (al-rabb) akan kelestariaannya, memanfaatkan dengan cara rahmat (wajar dan adil) dan mencegah terjadinya perusakan alam semesta sebagai sebuah kewajiban manusia dalam rangka pengabdiannya kepada Allah Ta'ala. Karena pada hakikatnya, segala sikap, perilaku atau perbuatan manusia (lahir dan batin) yang berkaitan dengan pemeliharaan, pelestarian dan pemanfaatan, atau eksploitasi sumber daya alam secara serampangan dan melampaui batas atau isyraf, haruslah dipertanggungjawabkan di hadapan Tuhan setelah kehidupan dunia ini berakhir.

\section{KESIMPULAN}

Kerusakan lingkungan hidup terjadi akibat adanya tindakan segelintir manusia tak bermoral, serakah, egois dan tamak. Mengeksploitasi kekayaan alam sebanyakbanyaknya di luar batas kewajaran, tanpa memperhatikan sistem ekosistem dan hukum

${ }^{51}$ Samidi, Tuhan, Manusia, dan Alam: Analisis Kitab Primbon Atassadhur Adammakna, dalam Shahih vol. 1, No. 1, Januari-Juni 2016, h. 14-26

52 Eko Prayetno, Kajian Al-Qur'an dan Sains tentang Kerusakan Lingkungan, dalam ALDZIKRA Jurnal Studi Ilmu Al-Qur'an Dan Al-Hadits http://ejournal.radenintan.ac.id/index.php/aldzikra Volume 12, No. 1, Juni Tahun 2018, h. 1-20

132 | Al-Fanar: Jurnal Ilmu Al-Qur'an dan Tafsir 
lingkungan hidup, berdampak negatif secara multidimensional terhadap kehidupan manusia dan makhluk lainnya yang berujung pada kehancuran dan kepunahan (fasad). Al-Qur'an secara detail menjelaskan terkait kata fasad dalam bentuk masdar menunjukkan kerusakan bersifat hissi/fisik, seperti banjir, pencemaran udara. Akan tetapi jika kata fasad berupa isim masdar bermakna kerusakan yang bersifat nonfisik, seperti kafir, syirik, munafik, dan semisalnya. Jadi kerusakan yang bersifat fisik pada hakikatnya merupakan akibat kerusakan bersifat non-fisik atau mental spiritual. Kehadiran revolusi spiritual berbasis Al-Qur'an solusi menumbuhkan kesadaran makhluk manusia untuk menjaga alam lingkungan sebagai tempat dan sumber kehidupan. Tidak dicemari, dikotori dan dirusak, melainkan dirawat, dikelola dan dilestarikan serta dimanfaatkan secara patut sesuai aturan ekosistem dan hukum lingkungan hidup disertai internalisasi nilai-nilai tauhid (spiritualitas) berbasis akhlak karimah yang rahmat dan humanis.

\section{DAFTAR PUSTAKA}

Armour, A \& R. Lang. Environmental Planning Resource book Land. Canada: Directorate Environment, 1975.

Al-Ashfani, Al-Raghib. Kamus Al-Qur'an, Jilid 3, terj.: Ahmad Zaini Dahlan, Jakarta: Pustaka Khazanah Fawaid, 2017.

Badan Pusat Statistik, Statistik Lingkungan Hidup Indonesia 2016, Jakarta: BPS, 2016.

BNPD, pengetahuan defenisi dan jenis bencana, dalam http://www.bnpd.go.id/

Darwis, H \& Mas'ud, H. Kesehatan Masyarakat dalam Perspektif Sosioantropologi. Makassar: SAH MEDIA dalam https:// www. researchgate.net/ publication/342183770_Hubungan_Ekologi_Dengan_Pelestarian_Lingkungan/ link/5ee7da6d299bf1 faac56aaf4/download, 2017.

DEPAG, Al-Qur'an dan Terjemahannya, Bekasi: Darul Haq, 2014.

Fazari, Saghara Luthfillah, Penegakan Hukum Lingkungan dan Pemanfaatan Ruang Udara. Jurnal Ekologi, Masyarakat \& Sains Volume 1, Nomor 1, 2020 ECOTAS http://journals. ecotas. org/index.php/ems

Giyanto, dkk., Status Terumbu KarangIndonesia 2017, Jakarta: Pusat Penelitian Oceonografi-LIPI, 2017.

Hamzah, Andi. Penegakan Hukum Lingkungan. Edisi Revisi. (Jakarta: Sinar Grafika, 2005.

http://www.ibnukatsironline.com/2015/04/tafsir-surat-al-baqarah-ayat-195.html

Jabir, Abu Bakar Al-Jazairi, Tafsir Al-Qur'an Al-Aisar, Jakarta: Darus Sunnah, 2008.

Jayadi, E.M. Ekologi Tumbuhan. Mataram: Institut Agama Islam Negeri (IAIN) Mataram, 2015.

Al-Maraghi, Ahmad MustafaTafsir Al-Maraghi, Juz 19, Semarang: Toha Putera, 1995.

Miri, Sayyed Mohsen, Prinsip-Prinsip Islam dan Filsafat Mula Sudra sebagai Basis Etis dan Kosmologis Lingkungan Hidup, dalam M. Mangunwijaya, dkk, ed, Menanam Sebelum Kiamat: Islam, Ekologi, dan Gerakan Lingkungan Hidup, .Jakarta: ICAS, 2009.

Misbahkhunur, Tanggung Jawab Terhadap Alam Dan Lingkungan, modul 8 universitas brawijaya. 
Montreal dan Soerjani, dkk. Pembangunan dan Lingkungan. Meniti Gagasan dan Pelaksanaan Sustainable Development. Jakarta: Yayasan Institut Pendidikan dan Pengembangan Lingkungan, 1977.

N.H.T. Siahaan, Hukum Lingkungan dan Ekologii Pembangunan, Jakarta; Erlangga, 2004.

Prayetno, Eko, Kajian Al-Qur'an dan Sains tentang Kerusakan Lingkungan, dalam ALDZIKRA Jurnal Studi Ilmu Al-Qur'an Dan Al-Hadits http://ejournal. radenintan. ac.id/index.php/al-dzikra Volume 12, No. 1, Juni Tahun 2018.

Putri, Vanya Karunia Mulia. Ekologi: Definisi, Ruang Lingkup, Asas dan Manfaatnya, $\quad$ https://www.kompas.com/skola/read/2021/04/16/163119269/ ekologi-definisi-ruang-lingkup-asas-dan-manfaatnya?page=all.

R., Utina. \& Wahyuni K.D. Ekologi dan Lingkungan Hidup, Gorontalo: UNG Press, 2009.

Safitri, D. Ekoturisme, Dalam Ekologi Sosial, Tangerang: Pustaka Mandiri, 2019

Samidi, Tuhan, Manusia, Dan Alam: Analisis Kitab Primbon Atassadhur Adammakna, dalam Shahih vol. 1, No. 1, Januari-Juni 2016.

Sari, Amelia Indah. Hubungan Ekologi dengan Pelestarian Lingkungan dalam https:// www.researchgate.net/publication/342183770_Hubungan_Ekologi__Dengan_ Pelestarian_Lingkungan/link/5ee7da6d299bf1 $\overline{f a a c 56 a a f 4 / d o w n l o a d ~}$

Setiono, Kudwiratri, dkk. Manusia Kesehatan Dan Lingkungan: Kualitas Hidup Dalam Perspektif Perubahan Lingkungan Global, Bandung: P.T. Alumni, 2007.

Shihab, M. Quraish, Tafsir al-Misbah, Volume 7, Jakarta : Lentera Ahti, 2000.

Sunu, Pramudiya. Melindungi Lingkungan dengan Menerapkan ISO 14001, Jakarta: Grasindo, 2001.

Suryadilaga, Muhammad Alfatih, Pemahaman Hadits Tentang Bencana (Sebuah Kajian Teologis Terhadap Hadits-Hadits Tentang Bencana), dalam essensia Vol. XIV No. 1 April 2013. 